\title{
FUNCTIONAL ASSESSMENT OF PATIENTS WITH CERVICAL MYELOPATHY WHO UNDERWENT SURGICAL TREATMENT
}

\author{
AVALIAÇÃO FUNCIONAL DE PACIENTES COM MIELOPATIA CERVICAL SUBMETIDOS \\ A TRATAMENTO CIRÚRGICO
}

\section{EVALUACIÓN FUNCIONAL DE LOS PACIENTES CON MIELOPATÍA CERVICAL SOMETIDOS A TRATAMIENTO QUIRÚRGICO}

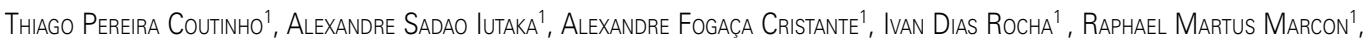

Reginaldo Perilo Oliveira', Tarcísio Eloy Pessoa de Barros Filho ${ }^{1}$

\begin{abstract}
Objective: Evaluate and correlate the functional response of patients with cervical myelopathy with the current clinical scores in patients who underwent surgical treatment. Methods: We analyzed medical records of 34 patients with cervical myelopathy who underwent four different types of surgery. All patients were evaluated preoperatively and postoperatively with the application of the JOA and Nurick questionnaires. Results: Functional clinical improvement was statistically significant. The mean preoperative JOA was $8.5 \pm 3.06$ and $10.7 \pm 3.9$ in the postoperative; Nurick was $3.2 \pm 1.1$ preoperatively and $2.8 \pm 1.3$ postoperatively. Conclusion: There is benefit with the surgical procedure in patients with cervical myelopathy. The neurological function after surgery depends on the previous function (the higher the duration of the previous symptoms, the greater the progression of the disease and, therefore, worse the neurological function) and the age is not a relevant factor of improvement, as already shown in other series. The clinical functional improvement of patients is visible with surgical treatment, regardless of surgical technique.
\end{abstract}

Keywords: Spinal cord compression; Spine fusion, Spondylosis; Spine; Laminectomy.

\section{RESUMO}

Objetivo: Avaliar e correlacionar a resposta funcional dos pacientes com mielopatia cervical com os escores clínicos já existentes, em pacientes que foram submetidos ao tratamento cirúrgico. Métodos: Trabalho retrospectivo com análise de 34 prontuários de pacientes portadores de mielopatia cenical que foram submetidos a quatro diferentes tipos de cirurgia. Todos os pacientes foram avaliados no pré e pós-operatório com a aplicação dos questionários de JOA e Nurick. Resultados: A melhora clínica funcional foi estatisticamente relevante. O JOA pré-operatório médio foi de 8,5 $\pm 3,06$ para

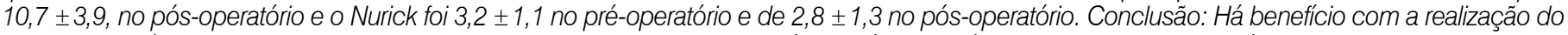
tratamento cirúrgico em pacientes com mielopatia cervical, a função neurológica pós-operatória depende da função prévia (quanto maior o tempo de sintomas, maior progressão e, com isso pior a função neurológica) e a idade dos pacientes não é fator relevante de melhora, como já mostrado em outras séries. A melhora funcional clínica dos pacientes, é visível com o tratamento cirúrgico, independente da técnica cirúrgica aplicada.

Descritores: Compressão da medula espinal, Fusão vertebral; Espondilose; Coluna vertebral; Laminectomia.

\section{RESUMEN}

Objetivo: Evaluar y correlacionar la respuesta funcional de los pacientes con mielopatía cervical con las puntuaciones clínicas vigentes en pacientes sometidos a tratamiento quirúrgico. Métodos: Se analizaron los registros médicos de 34 pacientes con mielopatía cervical que se sometieron a cuatro diferentes tipos de cirugía. Todos los pacientes fueron evaluados antes y después de la cirugía con la aplicación de los cuestionarios JOA y Nurick. Resultados: La mejoría clínica funcional fue estadísticamente significativa. El JOA preoperatorio promedio fue de 8,5 $\pm 3,06$ y 10,7 $\pm 3,9$ en el postoperatorio. El Nurick antes de la operación fue 3,2 $\pm 1,1$ y 2,8 \pm 1,3 después de la operación. Conclusión: Existe beneficio con el tratamiento quirúrgico en pacientes con mielopatía cervical. La función neurológica después de la cirugía depende de la función previa (cuanto mayor sea la duración de los síntomas anteriores, mayor será la progresión de la enfermedad y, por lo tanto, peor es la función neurológica) y la edad no es un factor relevante de la mejora, como ya se ha demostrado en otras series. La mejora clínica funcional de los pacientes es visible con el tratamiento quirúrgico, independientemente de la técnica quirúrgica y esto está directamente relacionado con su condición antes de la cirugía.

Descriptores: Compresión de la médula espinal; Fusión vertebral; Espondilosis; Columna vertebral; Laminectomía.

\section{INTRODUCTION}

Cervical myelopathy is a neurological pathology associated with a degenerative disease of the cervical spine resulting from a spinal cord compression. Vascular insufficiency and inflammation may also trigger the injury, contributing to an indirect compression. Calcification of the posterior longitudinal ligament, progressive cervical deformity, disc herniation, and trauma are the most common causes. Cervical myelopathy presents with clinical implications in the upper and/or lower limbs caused by compression of the spinal cord. ${ }^{1}$ Loss of coordination, weakness and tactile sensitivity are some of the most common symptoms.
The patient with myelopathy may present with tremors and the loss of fine hand movements, difficulty in gripping objects, such as buttons, or manipulating a hook fastener. ${ }^{2}$ The patient and/or their family observe changes in walking, such as a progressive limp or difficulty in maintaining the swing phase. In more advanced cases, urinary urgency, hesitancy, and even retention of urine may occur. Axial and/or radicular pain are common accompanied or not by muscle weakness and atrophy. In more advanced cases, signs of the involvement of the extrapyramidal system, such as hyperreflexia, clonus, absence of superficial reflexes, or the presence of pathologic reflexes, are observed. ${ }^{3}$

1. Spine Group, Institute of Orthopedics andTraumatology, Hospital das Clínicas da Faculdade de Medicina da Universidade de São Paulo (IOT-HCFMUSP)

Study conducted at the Institute of Orthopedics and Traumatology, Hospital das Clínicas da Faculdade de Medicina da Universidade de São Paulo (IOT-HCFMUSP). São Paulo, SP, Brazil. Correspondence: Rua Dr. Ovidio Pires de Campos, 333, São Paulo, SP, Brasil. 05403-010. tpcouto@ @erra.com.br 
Combined lumbar and cervical involvement may occur in up to $13 \%$ of patients, resulting in a potential for confusion with clinical findings consistent with low compression. ${ }^{4}$ One can perform early imaging studies such as simple, dynamic radiography and computed tomography (TC), however, the test of choice for visualizing nerve structures and adjacent soft parts of the column is the magnetic resonance imaging (MRI). ${ }^{5}$ Peripheral polyneuropathy, motor neuron disease, multiple sclerosis, cerebrovascular disease, and syringomyelia are some differential diagnoses. ${ }^{6}$

Conservative treatment of cervical myelopathy is empirical. There have been no well-developed clinical studies that have assessed the methods. The main conservative therapy consists of immobilization and anti-inflammatory medication, aiming to reduce static and/or dynamic compression. Although some conflict exists, most available evidence suggests that cases of cervical myelopathy with radiographic changes and symptoms are best resolved with surgery. ${ }^{7}$

The non-operative management of myelopathy is reserved for patients with mild symptoms or in the presence of comorbidities in patients facing a high risk in surgery. ${ }^{8,9}$ However, the indication for surgery is well established when there is progressive neurological worsening or in cases with severe myelopathy. ${ }^{10}$

Once surgical treatment is indicated, the access should be chosen: anterior, posterior, or combined. Factors such as lesion location, number of affected levels, patient age, preoperative neurological function, and the presence of abnormalities observed on MRI, such as spinal cord edema or myelomalacia, should be considered for the decision. ${ }^{11}$ The sagittal alignment of the spine is also an important factor; cervical kyphosis and instability of a degenerative nature are clear indications for the anterior approach. ${ }^{12,13}$ However, ossification of the posterior longitudinal ligament and congenital stenosis are indications for the posterior approach. ${ }^{14,15}$

The anterior approach involves discectomy with interbody fusion (ACDF) and corpectomy with interbody fusion (ACCF). The posterior approach involves laminectomy with or without arthrodesis and laminoplasty.

This work aims to conduct a functional evaluation of patients with cervical myelopathy of varied etiology undergoing different types of surgical treatment.

\section{METHODS}

The medical records of 34 patients, 24 males and 10 females, with cervical myelopathy who underwent surgical treatment between June 2008 to November 2011, registered at the spine outpatient clinic, were reviewed.

The mean age of patients at surgery was $57.9 \pm 12.3$ years (36-83 years). Spondyloarthritis (75\%), herniated disc (15\%), and trauma (5\%) were the main causes of myelopathy in our series. Patient follow-up was 17.8 months (3-42 months) on average. The average time from the onset of symptoms until surgery was 19.9 months (0-120 months).

Inclusion criteria were patients with cervical myelopathy who had undergone a prior pre- and postoperative functional assessment with the scale of the Japanese Orthopedics Association (JOA score $)^{16}$ (Table 1) and the Nurick ${ }^{17}$ score (Table 2), with the last postoperative evaluation occurring at least three months after surgery.

The surgeries were performed in patients with progressive myelopathy and with imaging consistent with the diagnosis by orthopedists belonging to the Spine Group of the Department of Orthopedics and Traumatology of our service. These encompassed surgeries via an anterior approach, discectomy with arthrodesis and corpectomy with arthrodesis, and via an posterior approach, laminectomy with arthrodesis and laminoplasty. The details of each technique and indication for each of them were not described in our work.

Patient charts were analyzed and separated by types of surgery, sex, age, race, educational level, time of onset of symptoms, and causes of myelopathy.

Data were statistically analyzed using SPSS 19.0 software for Windows. Descriptive statistics were performed to characterize the samples collected, such as the educational level, physical examination, procedures performed, and functional classification with the JOA and Nurick scores. The inferential statistical analysis was performed to verify the correlation of scores obtained pre- and post-surgical intervention for both the JOA and the Nurick scores, using the Pearson correlation test. Alpha error was accepted as $p<0.05$.

Table 1. JOA clinical evaluation.

\section{Motor function in upper limb:}

\begin{tabular}{l|l}
\hline Impossible to eat with a spoon or button a shirt & 0 \\
\hline Possible to eat with a spoon, but impossible to button a shirt & 1 \\
\hline Possible to button a shirt, but with great difficulty & 2 \\
\hline Possible to button a shirt, but with difficulty & 3 \\
\hline Normal & 4 \\
\hline
\end{tabular}

Motor function in lower limb:

\begin{tabular}{|c|c|}
\hline Impossible to walk & 0 \\
\hline Needs a cane or help on flat ground & 1 \\
\hline Needs help on stairs & 2 \\
\hline Walks without help, but slowly & 3 \\
\hline Normal & 4 \\
\hline \multicolumn{2}{|l|}{ Sensory function in upper limbs: } \\
\hline Apparent sensory disturbance & 0 \\
\hline Minimal sensory disturbance & 1 \\
\hline Normal & 2 \\
\hline \multicolumn{2}{|l|}{ Sensory function in lower limbs: } \\
\hline Apparent sensory disturbance & 0 \\
\hline Minimal sensory disturbance & 1 \\
\hline Normal & 2 \\
\hline \multicolumn{2}{|l|}{ Sensory function in trunk: } \\
\hline Apparent sensory disturbance & 0 \\
\hline Minimal sensory disturbance & 1 \\
\hline Normal & 2 \\
\hline \multicolumn{2}{|l|}{ Vesical function: } \\
\hline Urinary retention or incontinence & 0 \\
\hline Retention sensation and/or "leaking" and/or loss of low flow & 1 \\
\hline Urinary retention and/or increased urinary frequency & 2 \\
\hline Normal & 3 \\
\hline
\end{tabular}

Table 2. Nurick score, degree of neurologic deficit.

\begin{tabular}{c|l}
\hline Grade I & No difficulty in walking; \\
\hline Grade II & $\begin{array}{l}\text { Slight difficulty in walking that does not impede daily activities } \\
\text { or work; }\end{array}$ \\
\hline Grade III & $\begin{array}{l}\text { Difficulty in walking and daily activities with hands. } \\
\text { Does not need assisting device; }\end{array}$ \\
\hline Grade IV & Assisted walking (cane, walker); \\
\hline Grade V & Unable to walk. Confined to a bed or wheelchair. \\
\hline
\end{tabular}




\section{RESULTS}

The educational level of the patients was taken into account in the questionnaire responses and was divided as follows: elementary school (9 cases), junior high completed (12 cases), high school diploma (9 cases), and college degree (4 cases). Patients were also separated according to race: 29 White patients, 3 mixed race patients, and 2 Black patients, and by marital status: 11 single patients, 2 married patients, and 2 divorced.

The causes of myelopathy in our series were herniated disc, cervical canal stenosis, spondylolisthesis, and trauma. Any prior neurological deficit was also considered; $44 \%$ had a deficit on physical examination and $56 \%$ had none.

With respect to the procedures performed, we found: discectomy with anterior fusion ( $n=15)$, corpectomy with anterior fusion $(n=3)$, laminectomy with posterior fusion $(n=10)$, and posterior laminoplasty $(n=6)$. The number of intersomatic levels approached from C2 to T1 were $1(n=8), 2(n=12), 3(n=11)$, and 4 $(n=3)$ levels. (Figure 1)

The pre-JOA was $8.5 \pm 3.06$ on average, and $10.7+3.9$ in the postoperative evaluation.

It was observed through the correlation test that the higher the preoperative JOA score, the higher the postoperative JOA, and the lower the pre-score, the lower the post-score. $R=0.57, p=0.000$, where $R^{2}$ shows that $32 \%$ of the changes in the post-JOA were accounted for by the pre-JOA. Regression analysis shows that there is a 0.731 [95\% Cl: 0.35 to 1.10] increase in post-JOA for each increase unit of the pre-JOA. (Figure 2)

Regarding the Nurick score, the mean was $3.2 \pm 1.1$ preoperatively and $2.8+1.3$ postoperatively. A correlation was also observed that the higher the pre-score, the higher the post-score observed. $R=0.72, p=0.000$, where $R^{2}$ shows that $53 \%$ of the variation in the post-Nurick score was accounted for by the pre-Nurick score. (Figure 3)

Comparing JOA and Nurick score data with the percentage of postoperative improvement with the age of patients, we observed no correlation between the variables. Clinical improvement was defined as a percentage with respect to the post- and preoperative score. By applying a linear regression, an $\mathrm{R}^{2}$ value $<0.001$ was obtained in both the JOA and Nurick scores, that is, without statistical significance. (Figure 4)

Cervical myelopathy is the most common cause of spinal cord dysfunction in patients older than 50 years. ${ }^{18}$ Its history has an indolent course, and the neurological status worsens over time. However, there is no sign or method for understanding when neurological deterioration will occur. ${ }^{19}$ It is for this reason that the indication of surgical approach in patients with myelopathy becomes a challenge. The indication of the time for surgery and the surgical technique are controversial in medium intensity myelopathy. ${ }^{20}$ In our series, we approached the patients at different stages of the disease. Over $40 \%$ of these had some sort of neurological deficit, either sensory or motor, which correlated directly with the applied functional assessment scores.

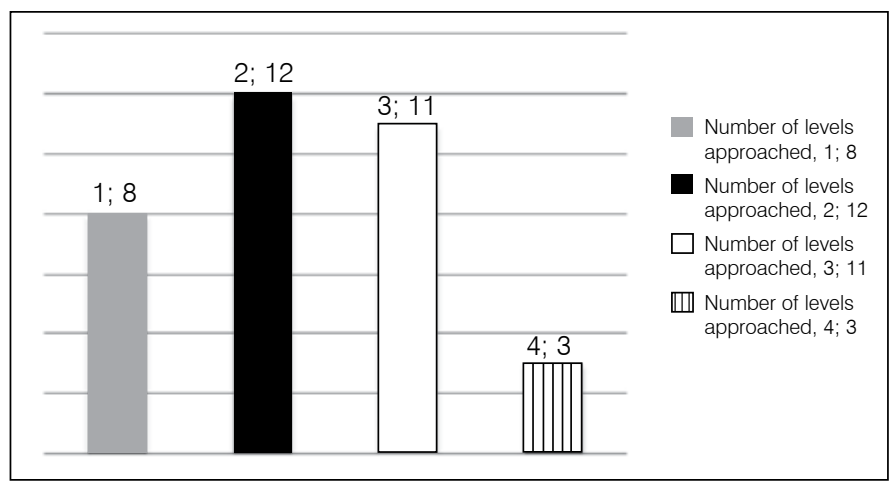

Figure 1. Correlation of the appearance of the number of levels approached by surgery.
Clarke and Robinson ${ }^{21}$ identified that about $75 \%$ of patients showed a progression of symptoms during conservative treatment, although half of them presented some period of clinical stability during the course of the disease. Matsumoto et al. ${ }^{22}$ described a series of cases where a third of patients with myelopathy showed a progression of symptoms with conservative management. Kadanka et al. ${ }^{8,9}$ suggested that $80 \%$ of myelopathy cases will improve with or without surgery.

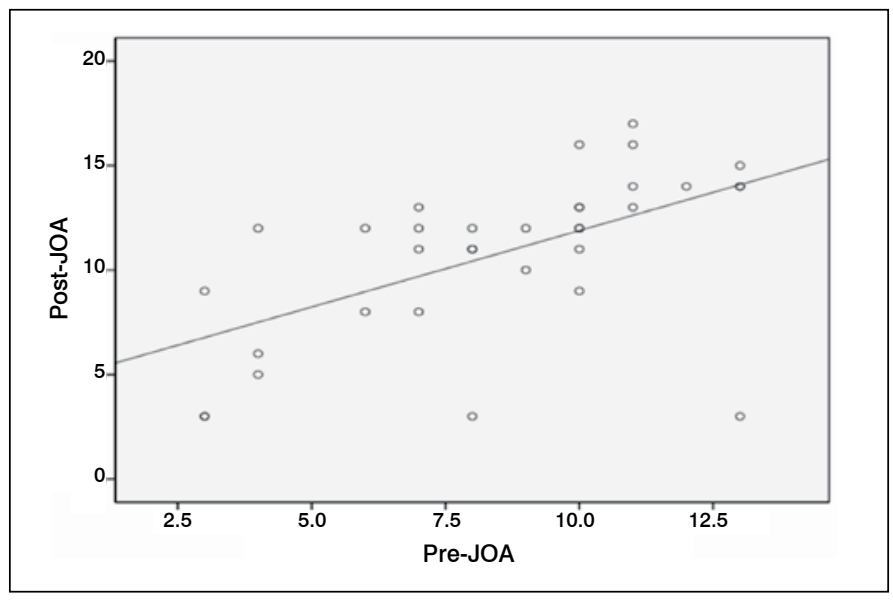

Figure 2. Correlation of pre- and postoperative JOA score.

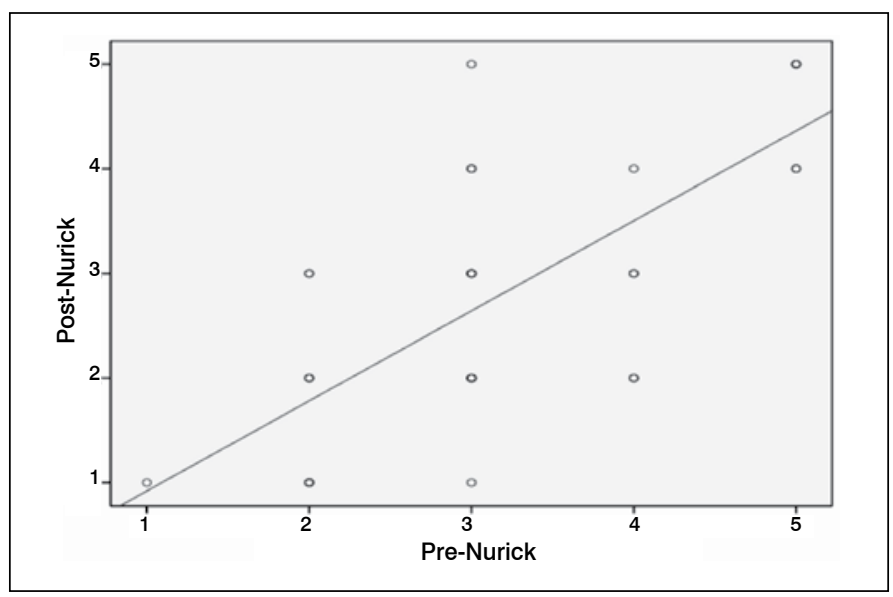

Figure 3. Correlation of pre-and postoperative Nurick score.

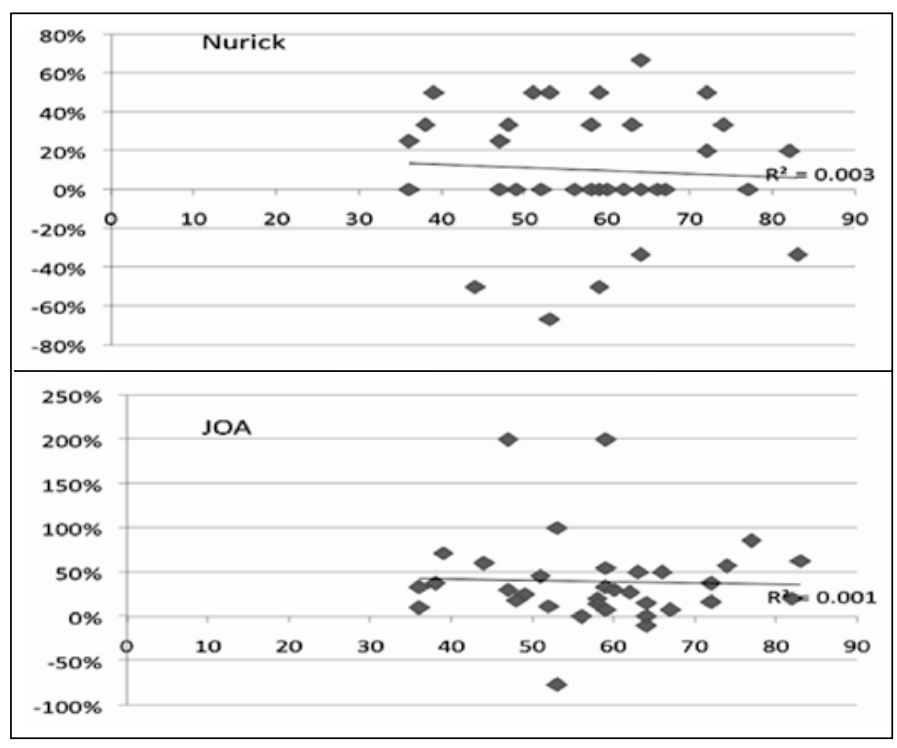

Figure 4. Relationship between patient age and percentage of clinical improvement. 
Discectomy with anterior arthrodesis was the most common type of surgery in our series, since it is a good option for the treatment of one or two levels, in contrast to what the literature says about the treatment of multiple levels. ${ }^{21,22}$ Decompression, laminectomy with arthrodesis, ${ }^{21}$ along with laminoplasty using a posterior approach, were other types of surgery performed. Laminoplasty is a procedure that is becoming more popular, particularly in cases where there is technical difficulty in the anterior decompression and the removal of the posterior longitudinal ligament where it is ossifying. ${ }^{7,23}$ Some authors suggest that when compared with the laminectomy, laminoplasty involves fewer complications, but causes more residual axial pain. ${ }^{24}$ Cervical corpectomy was used in severe cases of anterior bone and ligament compression of the spinal cord. ${ }^{25}$

The JOA score of the Japanese Orthopedics Association was established in 1975 to observe surgical treatment of cervical myelopathy. ${ }^{26}$ Although there have been problems regarding patient satisfaction in terms of quality of life and the treatment received, and it has undergone adaptations to different countries, it remains a widely used scale to assess patients with myelopathy. Being a questionnaire that is easily applied to and understood by patients, we believe it is a good way to assess the condition of our patients, since the educational level found in our patient series was predominantly primary school, $64 \%$.

The pre- and post-surgery comparison was performed in our series, over a period of at least 3 months, different from what was shown in the work of Yonenobu et al. ${ }^{27}$ who compared the results of corpectomy, laminectomy, and discectomy after 6 months of follow-up ${ }^{27,28}$, and the work of Chagas et al., ${ }^{29}$ who showed comparable results with an evaluation performed with at least 18 months postoperatively.
The work of Vitzthum and Dalitz, ${ }^{16}$ in which 43 patients with myelopathy undergoing surgery with an anterior approach were analyzed retrospectively, where patients were followed up for a minimum period of six months, shows that the JOA and Nurick scores showed statistically significant improvement after surgery, where $p<$ 0.001 for both, as was the case in our study. This same study shows that these results were similar to those shown by other authors. ${ }^{2,12,30}$

Yamazaki et al. ${ }^{31}$ and Fessler et al. ${ }^{32}$ showed that the evolution of the scores was significantly lower in older patients compared to younger ones, showing that age was not a predictor of improvement or worsening in the cases, as was shown in our series.

Machino et al., ${ }^{33}$ who followed 520 patients for a minimum period of 12 months, showed through the recovery rate that the values of the postoperative JOA differ according to the pre-JOA, indicating that the recovery of neurological function after surgery is strongly influenced by the severity of the preexisting disease, as was evidenced in our series.

\section{CONCLUSION}

Cervical myelopathy is a progressive disease requiring surgical intervention. The clinical-functional improvement of patients is visible with surgical treatment independent of the surgical technique, and this is directly related to their condition prior to surgery. We also concluded that patient age is not a significant predictor.

All authors declare no potential conflict of interest concerning this article.

\section{REFERENCES}

1. Rao RD, Currier BL, Albert TJ, Bono CM, Marawar SV, Poelstra KA, et al. Degenerative cervical spondylosis: clinical syndromes, pathogenesis, an management. J Bone Joint Surg Am. 2007;89(6):1360-78

2. Emery SE. Cervical spondylotic myelopathy: diagnosis and treatment. J Am Acad Orthop Surg. 2001;9(6):376-88.

3. Harrop JS, Hanna A, Silva MT, Sharan A. Neurological manifestations of cervical spondylosis: an overview of signs, symptoms, and pathophysiology. Neurosurgery. 2007;60(1 Supp1 1):S14-20.

4. Edwards WC, LaRocca SH. The developmental segmental sagittal diameter in combined cervical and lumbar spondylosis. Spine (Phila Pa 1976). 1985:10(1):42-9.

5. Yalamanchili PK, Vives MJ, Chaudhary SB. Cervical spondylotic myelopathy: factors in choosing the surgical approach. Adv Orthop. 2012;2012:783762.

6. Rao R. Neck pain, cervical radiculopathy, and cervical myelopathy: pathophysiology, natural history, and clinical evaluation. J Bone Joint Surg Am. 2002:84-A(10):1872-81.

7. Vitarbo $E$, Sheth RN, Levi AD. Open-door expansile cervical laminoplasty. Neurosurgery. 2007;60(1 Supp1 1):S154-9.

8. Kadanka Z, Mares M, Bednarík J, Smrcka V, Krbec M, Chaloupka R, et al. Predictive factors for mild forms of spondylotic cervical myelopathy treated conservatively or surgically. Eur J Neurol. 2005:12(1):16-24.

9. Kadanka Z, Mares M, Bednaník J, Smrcka V, Krbec M, Stejskal L, et al. Approaches to spondylotic cervical myelopathy: conservative versus surgical results in a 3-year follow-up study. Spine (Phila Pa 1976). 2002;27(20):2205-10.

10. Sampath P, Bendebba M, Davis JD, Ducker TB. Outcome of patients treated for cervical myelopathy. A prospective, multicenter study with independent clinical review. Spine (Phila Pa 1976). 2000;25(6):670-6.

11. Witwer $\mathrm{BP}$, Trost GR. Cervical spondylosis: ventral or dorsal surgery. Neurosurgery. 2007:60(1 Supp1 1):S130-6.

12. Suda K, Abumi K, Ito M, Shono Y, Kaneda K, Fujiya M. Local kyphosis reduces surgical outcomes of expansive open-door laminoplasty for cervical spondylotic myelopathy. Spine (Phila Pa 1976). 2003;28(12):1258-62.

13. Sodeyama T, Goto S, Mochizuki M, Takahashi J, Moriya H. Effect of decompression enlargement laminoplasty for posterior shifting of the spinal cord. Spine (Phila Pa 1976). 1999;24(15):1527-31.

14. Snow RB, Weiner H. Cervical laminectomy and foraminotomy as surgical treatment of cervical spondylosis: a follow-up study with analysis of failures. J Spinal Disord. 1993;6(3):245-50

15. Hukuda S, Mochizuki T, Ogata M, Shichikawa K, Shimomura Y. Operations for cervical spondylotic myelopathy. A comparison of the results of anterior and posterior procedures. J Bone Joint Surg Br. 1985;67(4):609-15.

16. Vitzthum HE, Dalitz K. Analysis of five specific scores for cervical spondylogenic myelopathy. Eur Spine J. 2007:16(12):2096-103.

17. Nurick $S$. The pathogenesis of the spinal cord disorder associated with cervical spondylosis. Brain. 1972;95(1):87-100

18. Kawakami M, Tamaki T, Iwasaki H, Yoshida M, Ando M, Yamada H. A comparative study of surgical approaches for cervical compressive myelopathy. Clin Orthop Relat Res. 2000;(381):129-36

19. LaRocca H. Cervical spondylotic myelopathy: natural history. Spine (Phila Pa 1976). 1988;13(7):854-5.

20. Yonenobu K. Cervical radiculopathy and myelopathy: when and what can surgery contribute to treatment? Eur Spine J. 2000:9(1):1-7.

21. Clarke E, Robinson PK. Cervical myelopathy: a complication of cervical spondylosis. Brain 1956;79(3):483-510.

22. Matsumoto $M$, Chiba $K$, Ishikawa M, Maruiwa $H$, Fujimura $Y$, Toyama $Y$. Relationships between outcomes of conservative treatment and magnetic resonance imaging findings in patients with mild cervical myelopathy caused by soft disc herniations. Spine (Phila Pa 1976). 2001;26(14):1592-8.

23. Herkowitz HN. A comparison of anterior cervical fusion, cervical laminectomy, and cervical laminoplasty for the surgical management of multiple level spondylotic radiculopathy. Spine (Phila Pa 1976). 1988:13(7):774-80.

24. Ebersold MJ, Pare MC, Quast LM. Surgical treatment for cervical spondylitic myelopathy. J Neurosurg. 1995;82(5):745-51.

25. Hirabayashi K, Bohlman HH. Multilevel cervical spondylosis. Laminoplasty versus anterior decompression. Spine (Phila Pa 1976). 1995:20(15):1732-4

26. Macdonald RL, Fehlings MG, Tator $\mathrm{CH}$, Lozano A, Fleming JR, Gentili F, et al. Multilevel anterior cervical corpectomy and fibular allograft fusion for cervical myelopathy. J Neurosurg. 1997;86(6):990-7.

27. Yonenobu K, Hosono $N$, Iwasaki $M$, Asano M, Ono K. Laminoplasty versus subtotal corpectomy. A comparative study of results in multisegmental cervical spondylotic myelopathy. Spine (Phila Pa 1976). $1992 ; 17(11): 1281-4$

28. Harrop JS, Naroji S, Maltenfort M, Anderson DG, Albert T, Ratliff JK, et al. Cervical Myelopathy. A Clinical and Radiographic Evaluation and Correlation to Cervical Spondylotic Myelopathy. Spine (Phila Pa 1976). 2010. Spine [Internet]. 2010 Feb 10 [cited 2012 Mar 18]: Available from: http://www.ncbi.nlm.nih.gov/pubmed/20150835,

29. Chagas H, Domingues F, Aversa A, Vidal Fonseca AL, de Souza JM. Cervical spondylotic myelopathy: 10 years of prospective outcome analysis of anterior decompression and fusion. Surg Neurol. 2005:64(Suppl 1):S1:30-5.

30. Houten JK, Cooper PR. Laminectomy and posterior cervical plating for multilevel cervical spondylotic myelopathy and ossification of the posterior longitudinal ligament: effects on cervical alignment, spinal cord compression, and neurological outcome. Neurosurgery. 2003:52(5):1081-7.

31. Yamazaki T, Yanaka K, Sato H, Uemura K, Tsukada A, Nose T. Cervical spondylotic myelopathy: surgical results and factors affecting outcome with special reference to age differences. Neurosurgery. 2003;52(1):122-6.

32. Fessler RG, Steck JC, Giovanini MA. Anterior cervical corpectomy for cervical spondylotic myelopathy. Neurosurgery. 1998;43(2):257-65

33. Machino M, Yukawa Y, Hida T, Ito K, Nakashima H, Kanbara S, et al. Can elderly patients recover adequately after laminoplasty?: a comparative study of 520 patients with cervical spondylotic myelopathy. Spine (Phila Pa 1976). 2012;37(8):667-71. 